raised by biodefence work will deter academic researchers from joining the field. "The security issues are going to be a new thing for a lot of the academic scientists who want to get involved in this," says Gigi Kwik, a fellow with the Johns Hopkins Center for Civilian Biodefense Strategies in Baltimore, Maryland.

Some of these issues involve regulations on who can work on dangerous pathogens, and where such research can be done. Other researchers expressed fears about the harsh scrutiny that biodefence is likely to attract. Earlier this year, for example, Thomas Butler, a biologist at Texas Tech University in Lubbock was dragged off to prison and publicly humiliated after wrongly accounting for the disposal of some samples of plague bacteria (see Nature Med. 9, 247; 2003).

Another factor causing reticence among academics is apprehension that the government will step in and regulate the kind of data that can be published. Some researchers complain that they were not consulted on a recent publishers' statement on biosecurity and scientific literature signed by this journal, among others (see Nature 421, 771; 2003), and that it may worsen that situation. "There should have been a dialogue, but there wasn't one," says microbiologist Stanley Falkow of Stanford University.

Critics have also claimed that the biodefence programme lacks the emphasis on basic research needed to crack its most important challenges. "This is really a long-term issue that is not going to be addressed in four or five years," says Falkow. Anthony Fauci, head of the National Institute of Allergy and Infectious Diseases, has repeatedly defended his agency's commitment to basic research. But of the $\$ 1.5$ billion in new biodefence money that the National Institutes of Health (NIH) will give out this year, \$454 million will go towards work on vaccines, diagnostics and therapeutics, and only $\$ 297$ million to basic research.

Despite these concerns, many observers remain confident that the vast sums of money being poured into biodefence will lead to gains against medically important diseases. "There will be a lot that comes from this investment that will have very broad applications, not just to threat agents, but to many other naturally occurring pathogens," says Cassell.

Others suggest that the size of the investment is sure to get academics involved. "As the infrastructure is enhanced, it will become easier and easier for more people to become involved in biodefence," says Gary Nabel, director of the NIH's Vaccine Research Center in Bethesda, Maryland. "I do hope there is interest out there."

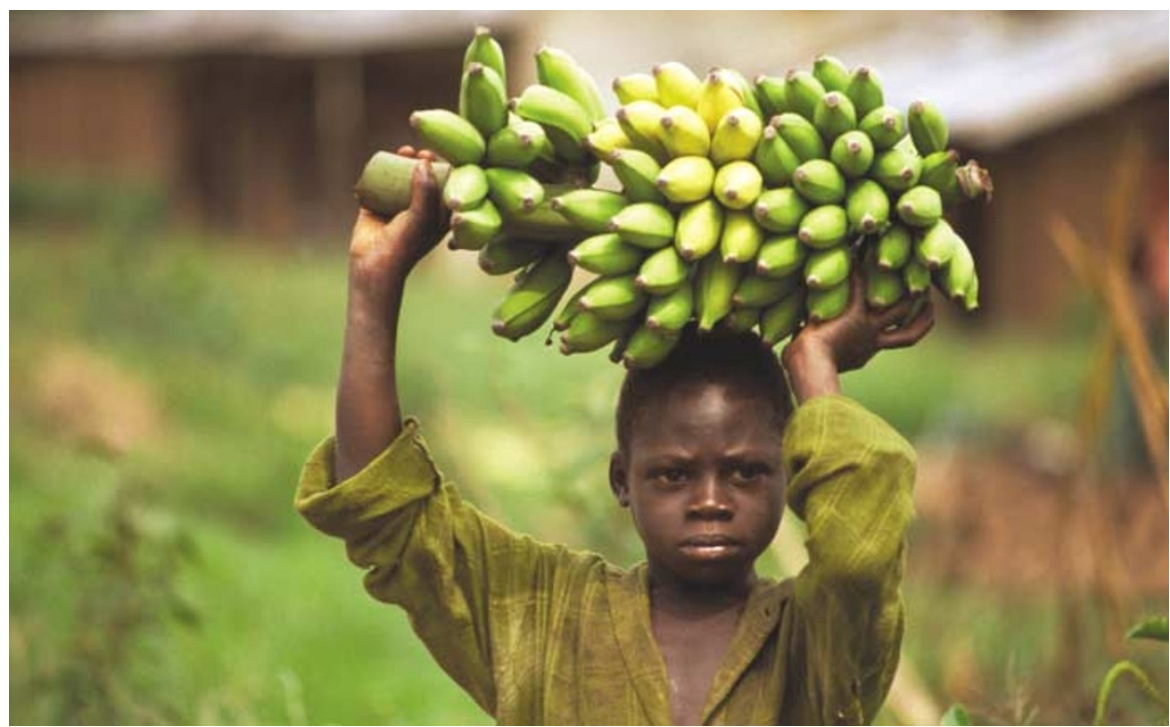

Future harvest: African farmers are set to get free rights to agricultural tools and technologies.

\title{
Biotech firms join charities in drive to help Africa's farms
}

\section{Hannah Hoag, Washington}

An alliance of agricultural biotechnology corporations, charities and aid organizations is pledging to help provide African farmers with the latest technologies at prices they can afford.

The African Agricultural Technology Foundation (AATF) has been set up in Nairobi following an initiative led by the New Yorkbased Rockefeller Foundation. Rockefeller president Gordon Conway says it will help to "unjam the logjam" of intellectual property rights that often prevents poor countries from exploiting advances in agricultural technologies such as plant breeding and transgenics.

Four companies - DuPont of Wilmington, Delaware; Dow AgroSciences of Indianapolis, Indiana; Monsanto of St Louis, Missouri; and Syngenta of Basel, Switzerland - say that they will provide the AATF with patented technologies and technical information without demanding royalties.

Eugene Terry, former director-general of the West Africa Rice Development Association in the Ivory Coast, who will head the new organization, says its priorities will be driven by the demands of Africa's farmers. "We don't want to push any technologies," he says. Farmers' organizations and African governments will be asked to suggest projects for the AATF, which will then help them to negotiate rights to the necessary tools and technologies.

The complex patent arrangements surrounding transgenic crops, as well as the technologies used to produce them, hamper efforts to devise practical solutions to the problems of farmers in poor countries, experts say. But the AATF says it will offer conventional management techniques, as well as new technologies, in response to farmers' problems.

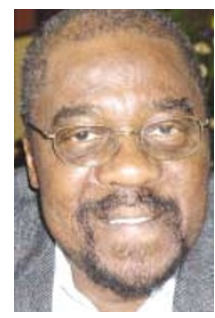

Eugene Terry: pledges to meet farmers' needs. increased levels of vitamins and minerals.

"What Africa needs is a diversity of approaches, and the AATF is an important addition to the portfolio," says Calestous Juma, director of science, technology and innovation at Harvard University's Center for International Development. Reliance on traditional farming methods alone will lead the continent to a "fateful destiny of isolation", he warns.

The Rockefeller Foundation has donated $\$ 1$ million to plan the operation, and the US Agency for International Development has put in $\$ 550,000$. Both will match these contributions this year, and Terry says he is in negotiations with other donors to raise the rest of the AATF's \$2.5-million annual operating budget.

The foundation will not have to pay royalties to the four biotechnology companies. But William Neibur, Dupont's vice-president of product development, warns that some patent arrangements will involve parties that will not necessarily provide intellectual property for free. "There will be royalty-free agreements, but there may also be ones that incur royalties," he says.

www.rockfound.org 